\title{
Literature Based Model as an Effort to Build Pedagogic Literacy Ability of Students Elementary School
}

\author{
Zakaria $^{1}$, Imam Mahfud ${ }^{2}$ \\ 1,2 STAI Binamadani Tanggerang, Indonesia \\ zakaria@stai-binamadani.ac.id
}

\section{ABSTRACT}

The literacy learning paradigm must be able to direct students to understand the values of pedagogic literacy. The government policy in the Regulation of the Minister of Education and Culture Number 23 of 2015 proclaims the school literacy movement or Gerakan Literasi Sekolah requiring students to read for 15 minutes as an effort to build a passion for reading, fostering imagination through reading activities with educational messages. Pedagogic literacy values must be built from an early age in an effort to create students with character. One learning model that is considered capable of building students' pedagogic literacy skills is the literature based model. The artile aims to analyze the description of pedagogic literacy in elementary school learning and the didactic design of a literature-based model in building the pedagogic literacy skills of elementary school students. The researchers used the content analysis or meta-analysis method. Sources of data in this study are journals and books related to literature-based models and pedagogic literacy. Then, the object of this research is the didactic design of the literature based model in building the pedagogic literacy skills of elementary school students. The result show that the literature-based model shows an increase in activity students including students' enthusiasm in following lessons, student interaction with teachers, student interaction with students, and student participation in concluding learning.

Keywords: Pedagogic Literacy Ability, Model Pedagogic Literacy, Students

How to cite Literation

Zakaria, Z., \& Mahfud, I., (2021). Literature Based Model As an Effort to Build Pedagogic Literacy Ability of Students Elementary School. IJoASER (International Journal on Advanced Science, Education, and Religion), 4(1). 1-8. https://doi.org/10.33648/ijoaser.v4i1.98

Journal Homepage https://ojs.staialfurqan.ac.id/IJoASER/

This is an open access article under the CC BY SA license

https://creativecommons.org/licenses/by-sa/4.0/

\section{INTRODUCTION}

It has become a common conversation that literacy skills in Indonesia are very low. Various international surveys have placed Indonesia's position on less literacy than satisfactory. As an example of the "Most Littered Nation In The World" study conducted by Central Connecticut State University in 2016, Indonesia was ranked 60th out of 61 countries in terms of reading interest (Nugrahanto, \& Zuchdi, 2019; Bunawan, Rangkuti, \& Yanti 2019). Furthermore, based on the Program for International Student Assessment (PISA) report which was just released, Tuesday, December 3, 2019 in the last four years, Indonesia's position has declined in all tested fields, namely reading, mathematics and science. Indonesia's reading score is ranked 72 out of 77 countries, 
then the math score is ranked 72 out of 78 countries, and the science score is ranked 70 out of 78 countries. The government, through the Ministry of Education and Culture, has made efforts to improve students' literacy skills through a program that has been implemented since 2016, namely the National Literacy Movement (GLN) OR IN Bahasa called Gerakan Literasi Nasional (GLN).. This program is part of the implementation of the Regulation of the Minister of Education and Culture Number 23 of 2015 concerning Cultivation of Character. The Ministry of Education and Culture established a working group for the National Literacy Movement to coordinate various literacy activities managed by related work units. The movement, which has been going on for almost 5 years, has been carried out in private and public schools from elementary to high school levels, which is known as the School Literacy Movement (GLS). However, the result is that literacy skills, especially school age children, are still low, this is due to several factors including the parents (family) who have not implanted reading habits from an early age, the lack of educational facilities or the lack of reading facilities, lack of motivation to read and the incessant of social media flow lately. This requires literacy learning from an early age.

Literacy which in English literacy comes from Latin, namely litera (letter) is often interpreted as literacy. Kern (2000) describes literacy as the ability to read and write. In addition, literacy also has the same meaning as learning and understanding reading sources. In connection with various kinds of literacy, Clay (2016) describes that literacy consists of early literacy, basic literacy, library literacy, media literacy, technology literacy, visual literacy. In the context of planting or teaching literacy from an early age, it is called early literacy. Mustafa (2008) states that early literacy is a reading and writing process characterized by literacy demonstrations, interactive collaboration between parents / teachers and children, based on daily needs and with minimal but direct teaching (at least direct). . The main characteristic of early literacy is informal learning, where children are taught according to their world, not feeling that they are learning. In Indonesia early literacy is the basis for the acquisition of later stages of literacy. The ability to read critically in literacy activities is the most basic thing and needs to be instilled in students in schools, especially elementary school students. One of the cultivation of literacy skills of elementary school children is with the right learning strategy, so that the objectives of learning literacy in schools can be achieved.

Literacy growth in schools can be done through routine and incidental activities. The activity is carried out in three stages of literacy, namely the habituation, development and learning stages. Learning that applies literacy strategies is essential for cultivating good, critical readers in any field. Based on several sources, seven characteristics of learning that apply literacy strategies that can develop metacognitive abilities can be summarized, namely:

1) monitoring text comprehension (students record their understanding before, when, and after reading),

2) the use of various modes during learning (multimodal literacy),

3) clear and explicit instructions,

4) the use of tools such as graphic organizers and checklists,

5) responses to various types of questions,

6) question making,

7) analysis, synthesis, and evaluation of texts,

8) summarizes the text content (Joyo, 2018).

One of the efforts made to attract students' interest in reading, especially elementary school students, is by applying a learning model as the right strategy. One 
model that can overcome this problem is by applying the Literature Based model. This model comes from the whole language approach which prioritizes authenticity, variations in teaching materials and seeks to integrate language skills (listening, speaking, reading, and writing).

The literacy learning paradigm must be able to direct students to understand the values of pedagogic literacy. The government policy in the Regulation of the Minister of Education and Culture Number 23 of 2015 proclaims the school literacy movement requiring students to read for 15 minutes as an effort to build a passion for reading, fostering imagination through reading activities with educational messages. Pedagogic literacy values must be built from an early age in an effort to create students with character. One learning model that is considered capable of building students' pedagogic literacy skills is the literature based model. Hence, it is necessary to make a breakthrough in instilling the values of pedagogic literacy of elementary school students, one of which is by applying a learning model that is a literature based model.

The literature based model is a learning model that can be used as an option for teachers to be applied in the activities of the school literacy movement in the classroom. However, there has been no research that examines how the literaturebased process is applied in detail to the process of the school literacy movement. (Silvia, et al, 2017). The literature-based instruction model which is based on the whole language approach seeks to integrate various language skills in classroom learning. The components of this model as expressed by Rothlein (1991) include (a) the teacher's explanation as a strategy towards teaching, (b) reading aloud or telling stories, (c) reading silently, (d) writing, (e) sharing reading experiences (sharing) , (f) independent activities. According to Rothlein, Liz \& Meinbach, A.M. (1991), Trotter (2020) the components of the literature based model (reading programs) are:

1) Teacher-Directed activities (Strategy Lesson) / the teacher directs.

2) Student-teacher conference / conference of students and teachers (the process of discussing reading).

3) Approaches for developing interest in reading / approaches to developing interest in reading

Based on the explanation above, this article aims to provide a conceptual description of the literature-based instruction model in building pedagogic literacy values of elementary school students. Then it is necessary to design the formulation of the problem in this research which can be proposed, namely as follows:

1) What is the description of pedagogic literacy in learning in elementary schools?

2) How is the didactic design of a literature based model in building pedagogic literacy skills of elementary school students?

\section{METHOD}

The approach used in this research is the content analysis / meta-analysis method. Fraenkel \& Wallen (2008) state that content analysis is a technique that researchers can use to study human behavior indirectly through analysis of their communication, such as: textbooks, essays, newspapers, novels, magazine articles, songs, advertising images and all types of communication that can be analyzed. Sources of data in this study are journals and books related to literature-based models and pedagogic literacy. Then, the object of this research is the didactic design of the literature based model in building the pedagogic literacy skills of elementary school students. 


\section{RESULT AND DISCUSSION}

\section{Description of pedagogic literacy in learning in elementary schools}

Pedagogic literacy is part of basic literacy skills that must be introduced, developed and cultivated in elementary school students. Cultivating pedagogic literacy skills begins with building a supportive learning environment, especially in language learning in elementary schools. Teaching materials, resources and learning media must contain pedagogic values so that pedagogic literacy can be embedded in students.

The paradigm of literacy learning in elementary schools today refers to the whole language where literacy learning is taught as a whole and not separately. In line with this, pedagogic literacy must be taught in an integrative and comprehensive manner in learning in primary schools. Most importantly, pedagogic literacy is needed by teachers for formal learning, and students can consciously respond to learning related to pedagogic literacy. Furthermore, the collaborative involvement of the pedagogic community is also able to improve pedagogic literacy teaching.

Therefore pedagogic liteation in learning in elementary schools so that students are able to read the symptoms or social and cultural realities around them. This is in line with the opinion of Freire \& Macedo (2005), which states that it is not just reading words but also reading the world, linking text between the contexts of human sociocultural life.

\section{Literature-based model didactic design in building pedagogic literacy skills of elementary school students}

Building the pedagogic literacy skills of elementary school students, of course, a learning environment that supports this process must be applied. For this reason, the teacher must be able to design a learning model that is able to build the pedagogic literacy skills of elementary school students. After students gain learning experiences in the form of knowledge, understanding and skills of pedagogic values and the ability to map student characteristics, it is necessary to design a learning model in this case a literature-based model in building the pedagogic literacy skills of elementary school students. The development design is in the form of planning, implementation and evaluation stages.

a. Planning stage

In this stage, it begins with the teacher's efforts to identify the learning characteristics of each student in his class. Teachers of all students get the same opportunity to actively participate in learning activities. Then the teacher designs a learning plan that is in accordance with the syllabus to discuss certain teaching materials so that students can achieve the established basic competencies after which the teacher plans learning activities that are interrelated with each other, taking into account the learning objectives and the learning process of students.

b. Implementation stage

At this stage the teacher implements learning according to plan and refers to the needs of students, uses learning approaches and learning resources according to the characteristics of students and seeks to use information and communication technology (ICT) in supporting learning. The use of learning resources and learning approaches must refer to the symptoms and sociocultural realities. Students are introduced to folk stories, problematic themes to 
be built based on the realities experienced by students so that the values of pedagogic literacy will be embedded in students

c. Evaluation stage

Every activity that we do must want to know the results. Likewise in the process of teaching and learning activities, a teacher when finished carrying out learning activities must know the achievement of the students' abilities. Therefore, evaluation is a stage that must be done to determine the results of the teaching and learning process. Learning evaluation must be carried out simultaneously so that learning objectives and student abilities can be achieved and well illustrated. Evaluation plays an important role in learning activities. Therefore, teacher must understand evaluation from design to implementation, especially in applying the literature-based learning model in building students' pedagogic literacy skills. This stage marks the condition in which the teacher is able to carry out the process and continuous learning of research, so that the model used is more effective and precise.

The finding of this research show that after applying of the literature-based model supported by school resources, such as teachers, teaching media and the school environment, students' character of pedagodic literacy gave emerge by theirself. The literature-based model shows an increase in activity students including students' enthusiasm in following lessons, student interaction with teachers, student interaction with students, and student participation in concluding learning. Other finding confirmed that literature-based model also develops students' ability to think deeply analyze (Kristini, 2020). In addition, the use of varied learning resources make students provide mutual reinforcement and various important information as addition to a problem solving (Lau, et al., 2018). Hence it can enrich students' knowledge.

This finding also confirmed that Literacy-based education is not only increase the value of learning and student activeness in the learning process, however provide practical learning methods. Literacy based learning is based on language skills that must be mastered by students (Noviana \& Julianto, 2018). Learning experiences in the form of knowledge and skills of pedagogic values continue to grow along with pedagogic interactions in the teaching and learning process. The students' pedagogic literacy skills grow properly. Other finding confirmed that Pedagogic literacy culture is achieved by providing reading habits reading book for 15 minutes before learning (Hastuti \& Leastari, 2018; Safitri, et al., 2019). Every child in school is required reading books reading local stories and stories people who have deep local wisdom reading. The finding supported by Gogahu, D. G. S., \& Prasetyo, T. (2020) that conduted research about improvement pedagogic literacy in students reading comprehension through e books story. Other finding was attractive because was integrated in digitalbased books story. Digital-based books that are known to educate students. By utilizing technology that is getting closer to the life of students, the E-bookstory can be packaged in a modern and more interactive manner that has a visual design, storyline, andfeatures integrativethat are of interest to students, which are presented in digital form, so that students can enjoy it various media methods. The development of Ebookstory media is designed to emphasize the presentation of story descriptions that support students' understanding oflearning materials thematic integrative, according to the characteristics of thecurriculum 2013, According to (Ratnasari \& Zubaidah, 2019), the use of E-bookstory provides benefits to students, namely it can help students learn about vocabulary. The finding also supported by Nopilda \& Kristiawan (2018), 
the pedagogic literacy grow when giving the habitual in reading and give students the opportunity to collect good ideas based on experience, practice, reading, listening, watching TV and brainstorming. In this activity, the writer invites students to share what they feel in literacy journals.

\section{CONCLUSION}

Pedagogic literacy is part of the basic literacy skills that elementary school students must have. The paradigm of literacy learning in Indonesia focuses on meaning that processes collaboratively and intact. One or the literacy learning that leads to that direction is by applying a literature-based model that refers to the whole language approach. The literature-based instruction model refers to a whole language approach that seeks to integrate various language skills in classroom learning. In addition, language learning requires assistance from various media that can support students to be interested. Whole language is a teaching approach that presents language in its entirety and not separately. To foster the pedagogic literacy skills of elementary school students, of course, a learning environment that supports this process must be applied. Teachers must be able to create learning models that are able to build pedagogic literacy abilities of elementary school students, one model that is considered capable of realizing the above is the literature-based instruction model.

\section{ACKNOWLEDGMENT}

The author would like to express his gratitude to all people who already helped in finishing this paper.

\section{AUTHOR CONTRIBUTION STATEMENT}

First author had contribution for collecting data in this research. Corresponding author was a corresponding person with editor, from submission until publish for this article. Another authors help to improve this research paper before submit to journal.

\section{REFERENCES}

Bunawan, W., Rangkuti, M. A., \& Yanti, J. (2019, December). High-Level Comprehension Skill by using Competencies PISA in Indonesia's Education System. In 4th Annual International Seminar on Transformative Education and Educational Leadership (AISTEEL 2019) (pp. 576-580). Atlantis Press. Google Scholar

Cajkler, W., \& Wood, P. (2016). Lesson study and pedagogic literacy in initial teacher education: Challenging reductive models. British Journal of Educational Studies, 64(4), 503-521. https:// doi.org/10.1080/00071005.2016.1164295

Clay, M. M. (2001). Change over time in children's literacy development. Heinemann. Google Scholar

Gogahu, D. G. S., \& Prasetyo, T. (2020). Pengembangan Media Pembelajaran Berbasis E-Bookstory untuk Meningkatkan Literasi Membaca Siswa Sekolah Dasar. Jurnal Basicedu, 4(4), 1004-1015. https:// doi.org/10.31004/basicedu.v4i4.493

Hartati, T, dkk. High Order Thinking Skill and Literacy Base Technological Pedagogical Content Knowledge (TPACK) in Order to Improve Students Learning Quality of in Job Primary School Teacher's Professional Educational Program. International Journal of Science and Applied Science: Conference Series. Vol.3 No.1 (2019) hal. 136-141 doi: 10..20961/ijsascs.v3i1.32552 
Hastuti, S., \& Lestari, N. A. (2018). Gerakan Literasi Sekolah: Implementasi Tahap Pembiasaan dan Pengembangan Literasi di SD Sukorejo Kediri. Jurnal Basataka (JBT), 1(2), 29-34. https:/ / doi.org/10.36277/ basataka.v1i2.34

Joyo, A. (2018). Gerakan Literasi dalam Pembelajaran Bahasa Indonesia Berbasis Kearifan Lokal Menuju Siswa Berkarakter. Jurnal KIBASP (Kajian Bahasa, Sastra dan Pengajaran), 1(2), 159-170. https:/ / doi.org/10.31539/kibasp.v1i2.193

Fraenkel, J. R. \& Wallen, N. E. (2007). How to Design and Evaluate Research in Education. Singapore: The McGraw-Hill Companies. Google Scholar

Freire, P., \& Macedo, D. (2005). Literacy: Reading the Word and the World. London: Routledge Classics. Google Scholar

Kern, Richard, (2000), Literacy and Language Teaching, Oxford: Oxford University Press. Google Scholar

Kristini, E. (2020). Pembelajaran Berbasis Literasi Berbantuan Media Tik dengan Metode Pemberian Tugas Untuk Meningkatkan Hasil Belajar PPKn Pada Siswa. Mimbar Ilmu, 25(3), 495-508. http:/ / dx.doi.org/10.23887/mi.v25i3.28376

Lau, K. H., Lam, T., Kam, B. H., Nkhoma, M., Richardson, J., \& Thomas, S. (2018). The role of textbook learning resources in e-learning: A taxonomic study. Computers $\mathcal{E}$ Education, 118, 10-24. https:// doi.org/10.1016/j.compedu.2017.11.005

Latip, A., \& Permanasari, A. (2015). Pengembangan Multimedia Pembelajaran Berbasis Literasi Sains Untuk Siswa SMP Pada Tema Teknologi. Edusains, 7(2), 160-171. http:/ / dx.doi.org/10.15408/es.v7i2.1761

Maclellan, Effie (2008) Pedagogical literacy: what it means and what it allows. Teaching andTeacher Education, 24 (8). pp. 1986-1992. ISSN 0742-051X https:// doi.org/10.1016/j.tate.2008.05.009

Musthafa, Bachrudin, (2008), Dari Literasi Dini ke Literasi Teknologi. Bandung: Center of Research on Education and Sociocultural Transformation. Google Scholar

Nopilda, L., \& Kristiawan, M. (2018). Gerakan literasi sekolah berbasis pembelajaran multiliterasi sebuah paradigma pendidikan abad ke-21. JMKSP (Jurnal Manajemen, Kepemimpinan, dan Supervisi Pendidikan), 3(2), 216-231. http:/ / dx.doi.org/10.31851/jmksp.v3i2.1862

Nofiana, M., \& Julianto, T. (2018). Upaya Peningkatan Literasi Sains Siswa Melalui Pembelajaran Berbasis Keunggulan Lokal. Biosfer: Jurnal Tadris Biologi, 9(1), 24-35. https://doi.org/10.24042/ biosf.v9i1.2876

Nugrahanto, S., \& Zuchdi, D. (2019, April). Indonesia PISA Result and Impact on The Reading Learning Program in Indonesia. In International Conference on Interdisciplinary Language, Literature and Education (ICILLE 2018) (pp. 373-377). Atlantis Press. https:/ / dx.doi.org/10.2991/icille-18.2019.77

Rothlein, Liz and Anita Meyer M, (1991), The Lietrature Connetion. London: Foresman and Company. Google Sholar

Ratnasari, E. M., \& Zubaidah, E. (2019). Pengaruh Penggunaan Buku Cerita Bergambar Terhadap Kemampuan Berbicara Anak. Scholaria: Jurnal Pendidikan dan Kebudayaan, 9(3), 267-275. https:// doi.org/10.24246/j.js.2019.v9.i3.p267-275

Sadulloh, Uyoh, dkk. Pedagogik (Ilmu Mendidik). Bandung: Alfabeta. 2019.

Safitri, L., Muslim, A. H., \& Hawanti, S. (2019). Pengaruh membaca 15 menit terhadap minat baca siswa Sekolah Dasar. Jurnal cakrawala pendas, 5(2). http:/ / dx.doi.org/10.31949/jcp.v5i2.1387

Silvia, Okeu Wila dan Djuanda, Dadan. (2017). “Model literature based dalam program gerakan literasi sekolah". Journal mimbar sekolahdasar. Vol 4 No 2. hal 160-171. https://doi.org/10.23819/mimbar-sd.v4i2.7799 
Sudarwan Danim. 2010. Pedagogi, Andragogi dan Heutagogi. Bandung; Penerbit Alfabeta.

Suwandi, Sarwiji. (2019). Pendidikan Literasi: Membangun Budaya Belajar, Profesionalisme Pendidik, dan Budaya Kewirausahaan untuk Mewujudkan Marwah Bangsa. Bandung: PT. Remaja Rosdakarya.

Trotter, D. (2020). The Literature of Connection: Signal, Medium, Interface, 1850-1950. Oxford University Press. Google Translate

Tunnell, Michael and Jacobs, James. (1998). Using "Real" Books: Research Findings on Literature Based Reading Instruction. The Reading Teacher, 42 (7), pp. 470-477,

Copyright Holder :

(c) Zakaria, Z., \& Mahfud, I., (2021).

First Publication Right :

(C) IJoASER (International Journal on Advanced Science, Education, and Religion)

This article is under:

CC BY SA 